THRESHOLDS OF ILLITERACY 
This page intentionally left blank 
transformative ideals of justice in ethical and political thought series editors

Drucilla Cornell

Roger Berkowitz 
This page intentionally left blank 


\section{THRESHOLDS OF ILLITERACY}

THEORY, LATIN AMERICA, AND THE CRISIS OF RESISTANCE

Abraham Acosta 
Copyright (C) 2014 Fordham University Press

All rights reserved. No part of this publication may be reproduced, stored in a retrieval system, or transmitted in any form or by any means-electronic, mechanical, photocopy, recording, or any other-except for brief quotations in printed reviews, without the prior permission of the publisher.

Fordham University Press has no responsibility for the persistence or accuracy of URLs for external or third-party Internet websites referred to in this publication and does not guarantee that any content on such websites is, or will remain, accurate or appropriate.

Fordham University Press also publishes its books in a variety of electronic formats. Some content that appears in print may not be available in electronic books.

Library of Congress Cataloging-in-Publication Data

is available from the publisher.

Printed in the United States of America

$\begin{array}{llllllll}\text { I6 } & \text { I5 } & \text { I } 4 & 5 & 4 & 3 & 2 & \text { I }\end{array}$

First edition

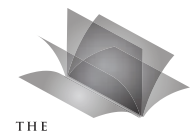

A M E R I C A N LITERATURES I N I T I AT I VE
A book in the American Literatures Initiative (ALI), a collaborative publishing project of NYU Press, Fordham University Press, Rutgers University Press, Temple University Press, and the University of Virginia Press. The Initiative is supported by The Andrew W. Mellon Foundation. For more information, please visit www.americanliteratures.org. 
To my wife, my son, and those we have lost along the way 
This page intentionally left blank 